\title{
New Selections Apricot of Breeding Program in Sahand Horticulture Research Station (SHRS)
}

\author{
J. Dejampour \\ Associate professor of Agricultural and Natural Resources Research Center of East Azerbaijan. \\ dejampour@yahoo.com
}

\begin{abstract}
Apricot (Prunus armeniaca L.) breeding project with aim of new cultivars creating through hybridization was started since 1998-99 at Sahand Horticultural Research Station. In this program, 32 crosses were carried out between local and foreign cultivars and 660 hybrid seeds were obtained. The seeds were planted in pots after stratification and second year the seedling screened in nursery and 450 genotypes were planted on farm. After bearing, vegetative and reproductive characteristics, flowering and fruit traits (more than 50 traits) of genotypes were studied and recorded according UPOV international guideline and IBPGIR descriptor of apricot for 4 years. The results of several years evaluation, 25 promising genotypes were selected based on grading and assigning values with respect to some important and effectiveness of traits. By comparison, AD412, AD732, AD412, AD1042, AD533 and AD841 were high and regular yield and resistance to cold of early spring. "DM 101" was the early ripening with the high fruit quality and suitable for fresh market. Fruit total soluble solids were from 17\% in AD741 to $26 \%$ in AD1033 among genotypes. The superior genotypes, as third phase of project, in different climatic areas were planted and they were evaluating since 2008. The characteristics of promise genotypes presented in this article.
\end{abstract}

Keywords: hybrid, promise genotypes, prunus armeniaca $L$.

\section{INTRODUCTION}

Iran is the most important apricot producer in the world with an annual average production more than 460000 tons with average yield about 9 tons/h in a normal year, but the apricot production fluctuates by due to climatic changes in Iran.

Iranian cultivars are often self - incompatible, high total soluble solid (TSS), sweet kernel, skin color light yellow and flesh color cream but most of genotypes are sensitive to unfavorable climatic condition in early spring (Layne, et al. 1996; Dejampour and Grigorian,2004). Therefore the main problems of our cultivars are low fruit set, bearing and irregular yield.

The ripening time among Iranian cultivars is very extension, for example ; Shastomi-I and Noraseh$\mathrm{M}$ are very early ripening (early of June) and MY-101 is very late ripening( mid of Aug.), but their fruit quality was not very good and commercial.

Propagation of apricot by seed during the past years led to a high genetic diversity in Iran (Layne, et al.1996). Therefore most of the local cultivars are need to improvement via hybridization with foreign cultivars, especially fruit bearing and fruit quality aspects (Dejampour and Grigorian. 2004). On the other hand, growers of apricot interested to new cultivars for fresh markets, drying and processing.

Breeding the 'perfect' apricot will result in a satisfied breeder, producer, exporter, and consumer. In order to obtain this, there are universal apricot breeding objectives, based on tree characteristics (rootstocks, tree vigor, growth habit, and productivity), floral biology (flowering date, intensity, and fertility), fruit characteristics (maturity, size, firmness, color, and taste), disease resistance, and climatic adaptation (Gulcan et al. 1995; Ham and Smith 2006).

Apricot culture mostly depends on the interaction between the climate, soil conditions, and the scion cultivar. Production, fruit quality, and time of harvest will be affected by these three factors (Ayanoglu and Kaska 1995). The effect of soil conditions can be minimized first by selecting the best suitable rootstock for the soil conditions (salinity, nematodes, etc.) and then by correct orchard management practices. Breeding for climatic adaptation, better fruit quality, and disease resistance is much more complicated. 


\section{J. Dejampour}

Some of the problems that need to be solved through breeding programs in the near future (Bassi 1997, 2006):

- the diversity and heterozygosity of the apricot germplasm,

- adaptation to the environment, which is hard to manage through standard crossing and selection due to time constraints and the speed of climate change,

- production (fresh and processed),

- fruit quality (size, firmness, aroma, flavor, skin color, sugar, and shape),

- mapping of the apricot genome,

- resistant or tolerant rootstocks and grafting compatibility with scion cultivars, and satisfying consumer preferences on an ongoing basis.

There are the several study as related to selection of apricot with fruit quality and resistance to late spring (Acka, and Sen. 1999), study on tolerance of apricot to winter temperature fluctuation and spring frost (Bassi, et al. 1995), investigation of effective pollination period and year - to - year variation of bearing of apricot (Egea and Burgos, 1992, Egea and Burgos, 1994) and breeding projects via crossing between different cultivars (Pennone, 1997; Audergon, et al.1997)

In 1998, this research was started via hybridization and collection of native genotypes as first apricot breeding program in Iran. Therefore crossing aimed at using some of the Iranian and European cultivars as parents in order to introduce the new cultivars with regular productivity and high fruit quality. Evaluation of their offspring and the characteristics of promising genotypes presented in this paper.

\section{Materials AND Methods}

This breeding program as first hybridization and improving of apricot (prunus armeniaca L.) cultivars in Iran has been carried out in Sahand Horticultural Research Station since 1994. This station is situated in North West of Iran in East - Azerbaijan province $\left(46^{\circ}, 45^{\prime} \mathrm{E}\right.$ and $38^{\circ}, 15^{\prime} \mathrm{N}$., elevation $1359 \mathrm{~m}$ ) and maximum temperature is $42^{\circ} \mathrm{C}$ and minimum temperature is $-22^{\circ} \mathrm{C}$. The main research projects of this station are on cultivation and improvement of apricot and almond. There are collection gardens of local and foreign elite genotypes in this station. In last year's ((Dejampour et al. 2012, Rahnemuon et al. 2012) 4 new apricot cultivars namely; "Maragehi-90", "Nasiri-90", "Ordebad-90" and "Aybatan" released among local superior genotypes in Sahand station, Iran.

The choice of the parents was based on some important traits; high and regular productivity, fruit size, TSS fruit, time of ripening and suitable for fresh market and possessing.

The cultivars utilized as parents in the breeding program were;

- Nasiri-90 : high TSS, large fruit size, high drying ability.

- Ordebad 90 : high drying ability, good flesh firmness

- Germezeh-Sh : large fruit size, high fruit flavor and suitable for fresh market.

- Aibatan : intermediate early ripening, large fruit size and good eating quality

- Maragehi 90 : high productivity, high TSS, good flesh firmness

- Shastomi-I : very early ripening

- My- $101 \quad$ : late ripening

- Canino : self - compatible, regular productivity

32 crossed were made between local and foreign cultivars via isolation of flowers and trees, crossing which were performed at last twice for each parents and repeated for 3 years. At ripening, fruits from each hybrid combination were separately gathered, the stone dried, stratified at $4{ }^{\circ} \mathrm{C}$ for 3 months.

After germination the hybrid seedlings were planted in plastic pots and second year the seedlings were transplanted in the selection field and spaced $1 \times 4 \mathrm{~m}$. 
Seedlings screening and evaluation included several phases:

1. In nursery, the selection carried out based on health and vigor of the seedling (1998-2001).

2. In the field, first selection conducted on the basis of fruit quality, resistance to disease (Bacterial canker, Peseudomonas syringea and shot hole, stigmina carpophila), chlorosis and spring cold hardness (2001 - 2007).

3. Second selection was on the basis of tree yield, regular productivity and fruit quality according to selection indices in breeding programs (2007-2009).

4. Forth selection as third phase of project was carried out on the basis of ecological adaptation in different climatic regions (since 2009).

The evaluation of genotypes were carried out according to IBPGIR descriptor and UPOV international guideline of apricot, based on grading and assigning values with respect to some important and effectiveness of pomological, morphological and reproductively characters. The promising selections grafted on the seedling rootstocks and were planted in evaluation field of three provinces (Tabriz, Karaj and Mashahd) with statistical RB design.

\section{RESULTS AND DISCUSSION}

In this breeding program, 660 hybrid seeds from all crosses and 200 seeds of open pollination of Maragehi 90 cultivar were obtained (Table-1,2). The seeds sterification and planted in nursery but 10-30 percent of seeds did not germination in different crosses. In first phase after nursery screening, 450 genotypes trees were planted in selection field. In second phase after first evaluation in field, 122 genotypes were selected based on fruit quality, resistance to disease, chlorosis and spring cold hardness. In third phase after second evaluation in field in order to study of traits stability for 3 years, 25 promising genotypes were selected as the best selections for testing in different ecological condition(Table 1,2).

Table 1. Different stage of the breeding program, crosses combination, selection and evaluation for self compatibility and drying ability

\begin{tabular}{|c|c|c|c|c|}
\hline Parents & $\begin{array}{l}\text { Nasiri } 90 \mathrm{x} \\
\text { Canino }\end{array}$ & $\begin{array}{c}\text { Nasiri } 90 \text { x Germezeh } \\
\text { Sh }\end{array}$ & $\begin{array}{c}\text { Ordobad 90 x } \\
\text { MY101 }\end{array}$ & $\begin{array}{l}\text { Maragehi 90 x } \\
\text { Canino }\end{array}$ \\
\hline Flowers & 400 & 550 & 510 & 646 \\
\hline Seeds & 73 & 83 & 90 & 120 \\
\hline Germinated seeds & 60 & 68 & 71 & 90 \\
\hline Seedlings & 57 & 68 & 69 & 85 \\
\hline Nursery screen & 55 & 62 & 64 & 81 \\
\hline First selection in field & 20 & 18 & 12 & 26 \\
\hline $\begin{array}{l}\text { Second selection in } \\
\text { field }\end{array}$ & 4 & 4 & 1 & 5 \\
\hline $\begin{array}{c}\text { Evaluation in } \\
\text { different areas } \\
\text { (promising } \\
\text { selections) } \\
\end{array}$ & $\begin{array}{l}\text { AD533,AD503, } \\
\text { AD1033, AD507 }\end{array}$ & $\begin{array}{l}\text { HS501, HS731, } \\
\text { AD811, HS643 }\end{array}$ & AD546 & $\begin{array}{c}\text { AD1042, } \\
\text { AD403,AD412, } \\
\text { AD732, DA626 }\end{array}$ \\
\hline Ability of drying & $\begin{array}{c}\text { AD503, AD1033 } \\
\text { AD507 }\end{array}$ & AD501,AD811 & - & AD626, \\
\hline
\end{tabular}

Table 2. Different stage of the breeding program, crosses combination, selection and evaluation for self compatibility and drying ability

\begin{tabular}{|c|c|c|c|c|}
\hline Parents & $\begin{array}{c}\text { Germezeh Sh x } \\
\text { Canino }\end{array}$ & Ordobad 90 x Aibatan & $\begin{array}{c}\text { Nasiri 90 x } \\
\text { Shastomi- I }\end{array}$ & $\begin{array}{c}\text { Gorbaneh 90 } \\
\text { (open pollination) }\end{array}$ \\
\hline Flowers & $\mathbf{6 2 0}$ & 490 & 410 & $\mathbf{8 8 0}$ \\
\hline Seeds & $\mathbf{1 0 1}$ & $\mathbf{1 2 0}$ & $\mathbf{8 6}$ & $\mathbf{1 8 0}$ \\
\hline Germination seeds & 67 & $\mathbf{5 6}$ & $\mathbf{5 8}$ & $\mathbf{1 6 5}$ \\
\hline Seedlings & $\mathbf{6 0}$ & $\mathbf{4 6}$ & $\mathbf{5 3}$ & $\mathbf{1 6 0}$ \\
\hline Nursery screening & $\mathbf{5 7}$ & $\mathbf{4 2}$ & $\mathbf{5 0}$ & $\mathbf{1 4 5}$ \\
\hline First selection in field & 15 & $\mathbf{5}$ & 1 & $\mathbf{2 1}$ \\
\hline $\begin{array}{c}\text { Second selection in } \\
\text { field }\end{array}$ & $\mathbf{3}$ & HS201, HS203, & DM 101 & AD1035, AD741 \\
\hline $\begin{array}{c}\text { Evaluation in different } \\
\text { areas (promising } \\
\text { selections) }\end{array}$ & $\begin{array}{c}\text { AD841, AD405, } \\
\text { AD743, }\end{array}$ & HS210,AD416,AD650 & & \\
\hline Drying ability & - & HS201, HS203 & & AD1035 \\
\hline
\end{tabular}




\section{J. Dejampour}

Among this population several genotypes were resistance to unfavorable weather condition in early spring and pollination time. By comparison, AD412, AD732, AD412, AD1042, AD533 and AD841 were high and regular yield and resistance to cold of early spring. This may be related to effective pollination period (EPP), self - compatibility rate and cold hardness of flower (Egea and Burgos, 1994; Bassi, et al. 1995).

"DM 101" was the early ripening promising selection with the high fruit quality and suitable for fresh market. Ripening time of this genotype was 7 days after Shastoni $-\mathrm{I}$ and 38 days before Canino Cultivar.

Fruit total soluble solids were from $17 \%$ in AD741 to $26 \%$ in AD1033 among genotypes, so these cultivars are suitable for fresh market and industrial applications. Fruit weights were from 34 in AD403 hybrid to 65 in AD643. Bearing habit among trees ranged from spurs to one year old branches and the blooming time among cultivars ranges from early to late was maximum 6 days and usually changes year to year.

Some of the important pomological and phonological characteristics of superior promising selections from apricot breeding program are described in below;

\section{AD412 (Maragehi $90 \times$ Canino)}

Yield: high and regular

Use: drying and fresh market

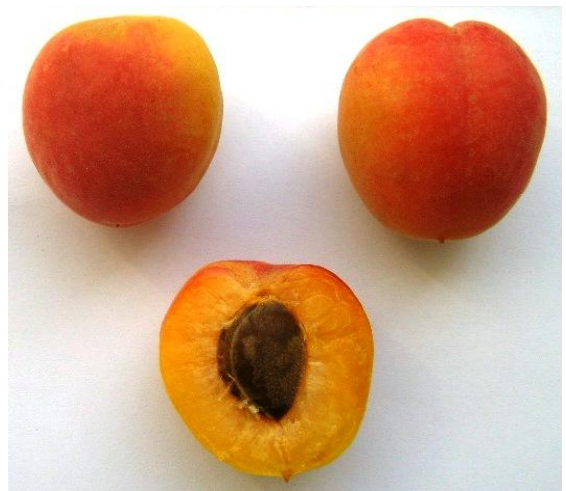

\begin{tabular}{|l|l|l|l|}
\hline Tree vigor & Intermediate & Fruit W./Stone W. & 16 \\
\hline Tree habit & Upright & Stone & free \\
\hline Type of bearing & Spurs and one year old shoots & Kernel taste & Sweet \\
\hline Fruit size & Medium & Time of flowering & Medium \\
\hline Over color & Red & Total Soluble Solids & $19 \%$ \\
\hline Skin color & Yellow & Fruit shape & Elliptic \\
\hline Flesh color & Light orange & Fruit weight & $51(\mathrm{~g})$ \\
\hline Firmness of flesh & Medium & Time of ripening & Medium \\
\hline
\end{tabular}

AD841 (Germezeh Sh $\times$ Canino)

Yield : high

Use : drying and fresh market

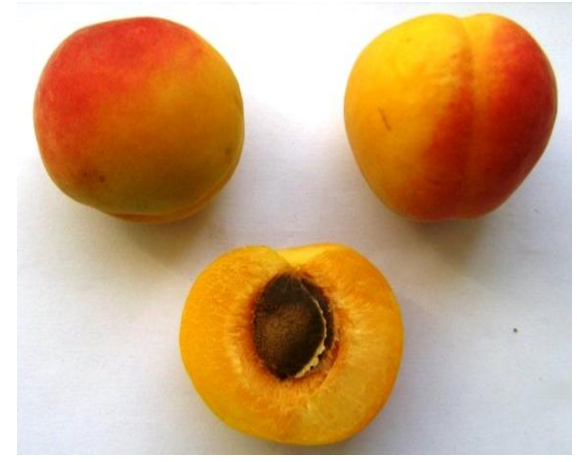

\begin{tabular}{|l|l|l|l|}
\hline Tree vigor: & Strong & Fruit W./Stone W & 20.43 \\
\hline Tree habit & Upright & Stone $:$ & Free \\
\hline Type of bearing & Spurs and one year old shoots & Kernel taste : & Sweet \\
\hline Fruit size & Medium & Time of flowering : & Medium \\
\hline Over color & Red & Total Soluble Solids & $18 \%$ \\
\hline Skin color & Yellow & Fruit shape & Round \\
\hline Flesh color & Fruit weight & $53(\mathrm{~g})$ \\
\hline Firmness of flesh & Ledium & Time of ripening & Medium \\
\hline
\end{tabular}




\section{AD741 (Maragehi $90 \times$ Canino)}

Yield: high and regular

Use : drying and processing

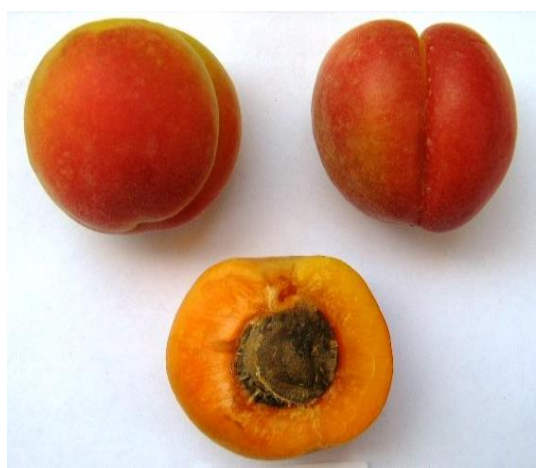

\begin{tabular}{|l|l|l|l|}
\hline Tree vigor & Intermediate & F W/S W & 15.80 \\
\hline Tree habit & Spreading & Stone & Semi-clinging \\
\hline Type of bearing & Mostly one year old shoots & Kernel taste & Weak bitterness \\
\hline Fruit size & Large & Time of flowering & Medium \\
\hline Over color & Red & Total Soluble Solids & $17 \%$ \\
\hline Skin color & Yellow & Fruit shape & Round \\
\hline Flesh color & Orange & Fruit weight & $60(\mathrm{~g})$ \\
\hline Firmness of flesh & Firm & Time of ripening & Medium \\
\hline
\end{tabular}

AD643 (Ordobad $90 \times$ Germezeh Sh)

Yield : high

Use : drying

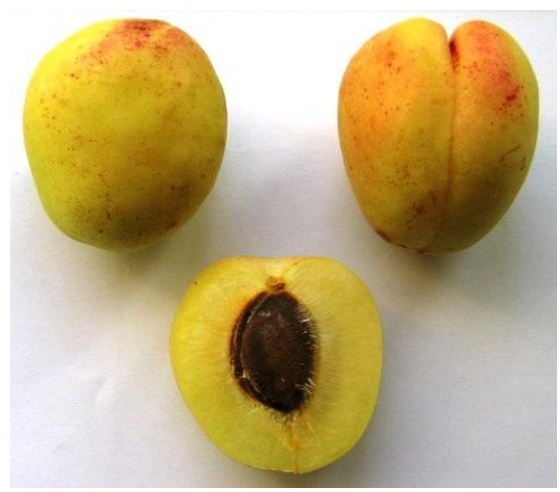

\begin{tabular}{|l|l|l|l|}
\hline Tree vigor & Strong & Fruit W./Stone W. & 19.86 \\
\hline Tree habit & Spreading & Stone & Free \\
\hline Type of bearing & Spurs and on one year old shoots & Kernel taste & Sweet \\
\hline Fruit size & Large & Time of flowering & Medium \\
\hline Over color & Slight & Total Soluble Solids & $20 \%$ \\
\hline Skin color & Yellowish & Fruit shape & Ovate \\
\hline Flesh color & Cream & Fruit weight & $65(\mathrm{~g})$ \\
\hline Firmness of flesh & Firm & Time of ripening & Medium \\
\hline
\end{tabular}

AD 732 (Maragehi $90 \times$ Canino)

Yield : very high and regular

Use : processing 
J. Dejampour

\begin{tabular}{|l|l|l|l|}
\hline Tree vigor & Intermediate & Fruit W./Stone W. & 16.83 \\
\hline Tree habit & Spreading & Stone & Free \\
\hline Type of bearing & Mostly on one year old shoots & Kernel taste & Sweet \\
\hline Fruit size & Medium & Time of flowering & Medium \\
\hline Over color & Red & Total Soluble Solids & $18 \%$ \\
\hline Skin color & Green- Yellowish & Fruit shape & Round \\
\hline Flesh color & Light orange & Fruit weight & $45(\mathrm{~g})$ \\
\hline Firmness of flesh & Medium & Time of ripening & Intermediate late \\
\hline
\end{tabular}

DM101 (Nasiri $\times$ Shashtomi -I)

Yield : medium

Use : fresh market

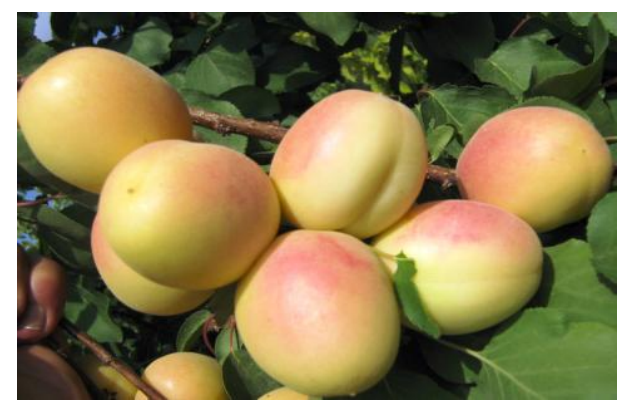

\begin{tabular}{|l|l|l|l|}
\hline Tree vigor: & Intermediate & Fruit W./Stone W. & 21.57 \\
\hline Tree habit & Upright & Stone & Free \\
\hline Type of bearing & Mostly on spurs & Kernel taste & Sweet \\
\hline Fruit size & Medium & Time of flowering & Medium \\
\hline Over color & Red & Total Soluble Solids & $17 \%$ \\
\hline Skin color & Yellowish & Fruit shape & Heart shaped \\
\hline Flesh color & Light orange & Fruit weight & $58(\mathrm{~g})$ \\
\hline Firmness of flesh & Medium & Time of ripening & Early \\
\hline
\end{tabular}

\section{HS731 (Germezeh Sh $\times$ Nasiri 90)}

Yield : high

Use : fresh market

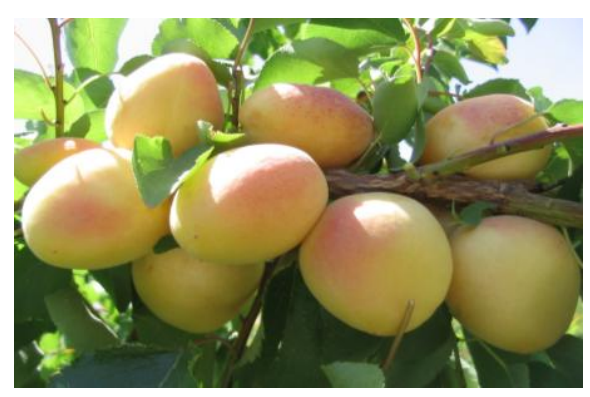

\begin{tabular}{|l|l|l|l|}
\hline Tree vigor & Intermediate & Fruit W. /Stone W. & 15.18 \\
\hline Tree habit & Up right & Stone & Free \\
\hline Type of bearing & Mostly on One year old shoots & Kernel taste & Sweet \\
\hline Fruit size & Large & Time of flowering & Medium \\
\hline Over color & Red & Total Soluble Solids & $19 \%$ \\
\hline Skin color & Yellow & Fruit shape & Ovate \\
\hline Flesh color & Light orange & Fruit weight & $59(\mathrm{~g})$ \\
\hline Firmness of flesh & Medium & Time of ripening & Medium \\
\hline
\end{tabular}

\section{HS203 (Nasiri $90 \times$ Maragehi 90)}

Yield : high

Use : drying and fresh market 
New selections apricot of breeding program in Sahand Horticulture Research Station (SHRS)

\begin{tabular}{|l|l|l|l|}
\hline Tree vigor & Intermediate & Fruit W. /Stone W. & 15 \\
\hline Tree habit & Spreading & Stone & Free \\
\hline Type of bearing & Mostly on One year old shoots & Kernel taste & Sweet \\
\hline Fruit size & Large & Time of flowering & Medium \\
\hline Over color & Red & Total Soluble Solids & $22 \%$ \\
\hline Skin color & Yellowish & Fruit shape & Ovate \\
\hline Flesh color & Orange & Fruit weight & $55(\mathrm{~g})$ \\
\hline Firmness of flesh & Firm & Time of ripening & Medium \\
\hline
\end{tabular}

\section{AD 405 (Germezeh Sh $\times$ Canino)}

Yield : High

Use : fresh market

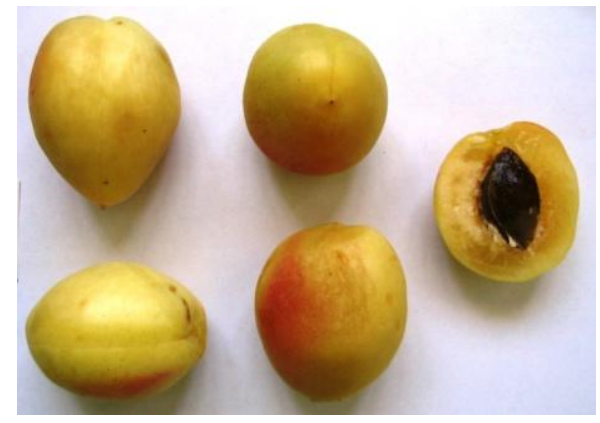

\begin{tabular}{|l|l|l|l|}
\hline Tree vigor & Intermediate & Fruit W. /Stone W. & 18.91 \\
\hline Tree habit & Up right & Stone & Free \\
\hline Type of bearing & Mostly on One year old shoots & Kernel taste & Sweet \\
\hline Fruit size & Medium & Time of flowering & Medium \\
\hline Over color & Red & Total Soluble Solids & $19 \%$ \\
\hline Skin color & Yellow & Fruit shape & Ovate \\
\hline Flesh color & Cream & Fruit weight & $42(\mathrm{~g})$ \\
\hline Firmness of flesh & Medium & Time of ripening & Medium \\
\hline
\end{tabular}

\section{HS201 (Ordobad $\times$ Maragehi 90)}

Yield : High

Use : Drying and fresh

\begin{tabular}{|l|l|l|l|}
\hline Tree vigor & Intermediate & Fruit W. /Stone W. & 15.18 \\
\hline Tree habit & Up right & Stone & Free \\
\hline Type of bearing & Mostly on spurs & Kernel taste & Sweet \\
\hline Fruit size & Medium & Time of flowering & Medium \\
\hline Over color & Red & Total Soluble Solids & $23 \%$ \\
\hline Skin color & Yellowish & Fruit shape & Heart shaped \\
\hline Flesh color & Light orange & Fruit weight & $49(\mathrm{~g})$ \\
\hline Firmness of flesh & Medium & Time of ripening & Medium \\
\hline
\end{tabular}

\section{AD503 (Nasiri $90 \times$ Canino)}

Yield : high

Use : drying and fresh market

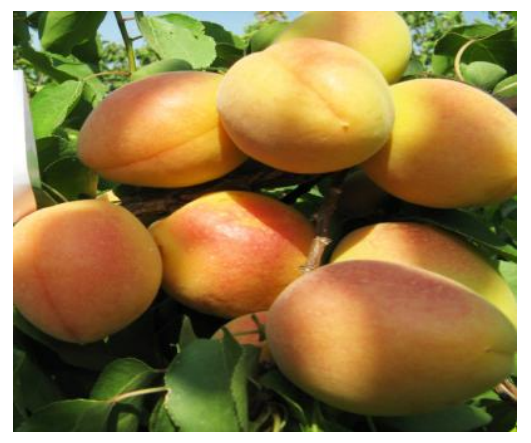




\begin{tabular}{|l|l|l|l|}
\hline \hline Tree vigor & Strong & Fruit W. IStone W. & 21.64 \\
\hline Tree habit & Spreading & Stone & Free \\
\hline Type of bearing & Mostly on one year old shoots & Kernel taste & Sweet \\
\hline Fruit size & Large & Time of flowering & Medium \\
\hline Over color & None & Total Soluble Solids & $19 \%$ \\
\hline Skin color & Green-yellowish & Fruit shape & Ovate \\
\hline Flesh color & Orange & Fruit weight & $60(\mathrm{~g})$ \\
\hline Firmness of flesh & Firm & Time of ripening & Medium \\
\hline
\end{tabular}

AD1033 (Nasiri $90 \times$ Canino)

Yield : high

Use : drying and fresh market

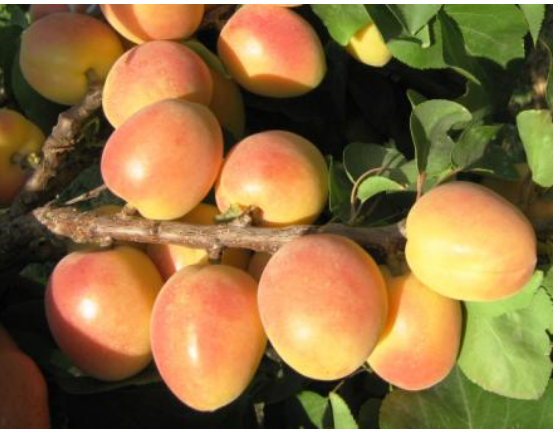

\begin{tabular}{|l|l|l|l|}
\hline Tree vigor & Intermediate & Fruit W. /Stone W. & 15.68 \\
\hline Tree habit & Spreading & Stone & Free \\
\hline Type of bearing & Mixed & Kernel taste & Sweet \\
\hline Fruit size & Large & Time of flowering & Medium \\
\hline Over color & Red & Total Soluble Solids & $26 \%$ \\
\hline Skin color & Yellow & Fruit shape & Ovate \\
\hline Flesh color & Light orange & Fruit weight & $54(\mathrm{~g})$ \\
\hline Firmness of flesh & Medium & Time of ripening & Medium \\
\hline
\end{tabular}

AD1042 (Maragehi $90 \times$ Canino)

Yield : High and regular

Use : drying and fresh market

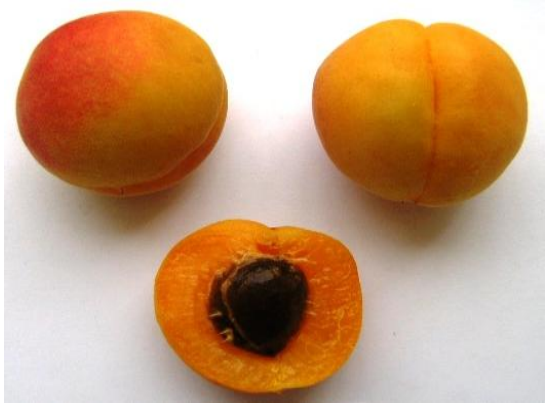

\begin{tabular}{|l|l|l|l|}
\hline Tree vigor & Intermediate & Fruit W. /Stone W. & 15.33 \\
\hline Tree habit & Up right & Stone & Free \\
\hline Type of bearing & Mixed & Kernel taste & Sweet \\
\hline Fruit size & Medium & Time of flowering & Medium \\
\hline Over color & Red & Total Soluble Solids & $19 \%$ \\
\hline Skin color & Light orange & Fruit shape & Round \\
\hline Flesh color & orange & Fruit weight & $45(\mathrm{~g})$ \\
\hline Firmness of flesh & Medium & Time of ripening & Medium \\
\hline
\end{tabular}

AD811 (Germezeh Sh $\times$ Maragehi 90)

Yield : High

Use : drying and fresh market 
New selections apricot of breeding program in Sahand Horticulture Research Station (SHRS)

\begin{tabular}{|l|l|l|l|}
\hline Tree vigor & Strong & Fruit W. /Stone W. & 20.22 \\
\hline Tree habit & Up right & Stone & Free \\
\hline Type of bearing & Mostly on One year old shoots & Kernel taste & Sweet \\
\hline Fruit size & Large & Time of flowering & Medium \\
\hline Over color & Red & Total Soluble Solids & $20 \%$ \\
\hline Skin color & Yellow & Fruit shape & Oblong \\
\hline Flesh color & Orange & Fruit weight & $55(\mathrm{~g})$ \\
\hline Firmness of flesh & Medium & Time of ripening & Medium \\
\hline
\end{tabular}

\section{AD 403 (Maragehi90 $\times$ Canino)}

Yield : medium

Use : drying and fresh market

\begin{tabular}{|l|l|l|l|}
\hline Tree vigor & Intermediate & Fruit W. /Stone W. & 15.5 \\
\hline Tree habit & Spreading & Stone & Free \\
\hline Type of bearing & Mostly on one year shoots & Kernel taste & Sweet \\
\hline Fruit size & Medium & Time of flowering & Medium \\
\hline Over color & Red & Total Soluble Solids & $18 \%$ \\
\hline Skin color & Yellow & Fruit shape & Elliptic \\
\hline Flesh color & Light orange & Fruit weight & $34(\mathrm{~g})$ \\
\hline Firmness of flesh & Medium & Time of ripening & Medium \\
\hline
\end{tabular}

\section{HS210 (Ordobad $90 \times$ Germezeh Sh.) \\ Yield : medium}

Use : drying and fresh market
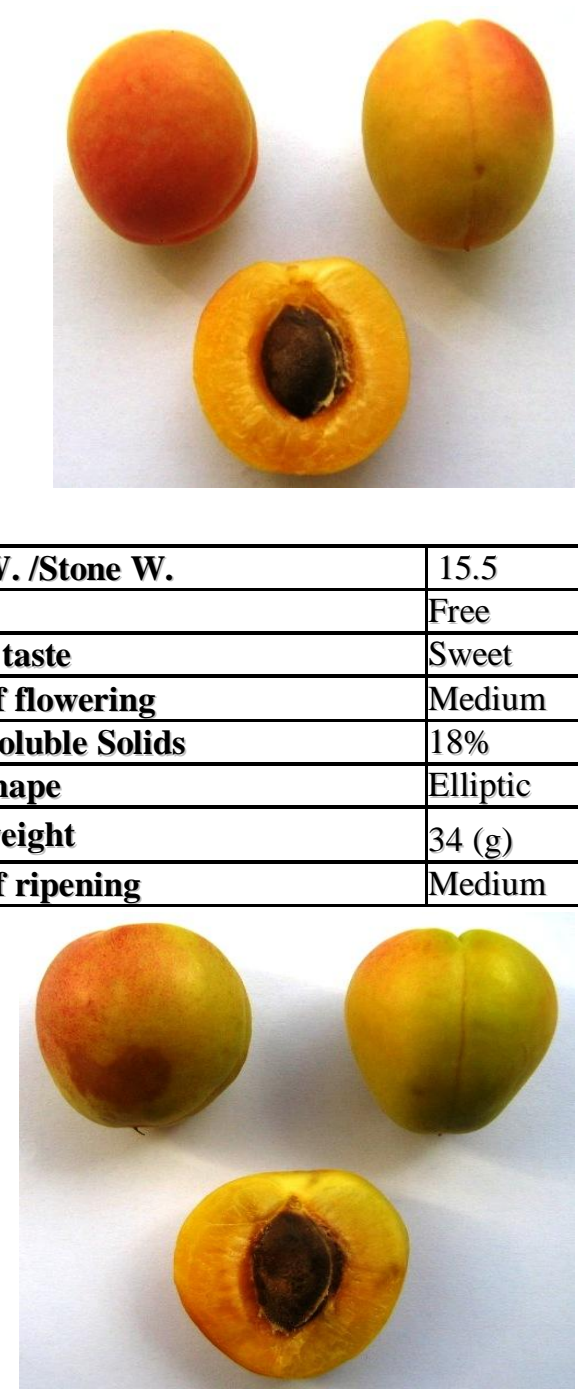

\begin{tabular}{|l|l|l|l|}
\hline Tree vigor & Intermediate & Fruit W. /Stone W. & 23.73 \\
\hline Tree habit & Up right & Stone & Free \\
\hline Type of bearing & Mostly on spurs & Kernel taste & Sweet \\
\hline Fruit size & Very Large & Time of flowering & Medium \\
\hline Over color & Red & Total Soluble Solids & $27 \%$ \\
\hline Skin color & Green-yellowish & Fruit shape & Heart shaped \\
\hline Flesh color & Light orange & Fruit weight & 73(g) \\
\hline Firmness of flesh & Medium & Time of ripening & Medium \\
\hline
\end{tabular}

In this research, heritability of some traits were clear, for example; the round shape of fruit was dominant over elongated, light cream flesh of fruit was dominant over the yellow and orange color and sweet kernel (seed) was dominant over bitter kernel in progeny(Singh, et al., 2001; Vachun, 2003). The weight fruit with sugar content and round shape of fruit were negative correlation. However apricot has a great deal of genetic variability (Bailey and Hough 1975), but information on apricot traits' heritability is very scarce. There is still uncertainty about some characteristics, such as 


\section{J. Dejampour}

fruit size, color (skin and background), flavor, red blush, seed (sweet and bitter), and time of ripening that can be influenced by climatic conditions or polygenic control. Therefore, the average performance of the progeny could be predicted on the basis of the phenotype of the parents in most traits (Layne et al. 1996; Bassi 2006).

In order to introduce or release of the "elite" genotypes, they grafted on seedling rootstocks and were planted in three provinces (Tabriz, Karaj and Mashahd) of Iran with different climatic condition for field evaluation and climatic adaptation.

\section{REFERENCES}

[1] Akca, Y., S. Sen, M. 1993. Selecting apricots with good quality and resistance to late spring frosts in Gurun. progress in temprature fruit breeding: $117-178$.

[2] Bassi, D. (2006) Apricot breeding: update and perspectives. Acta Horticulturae 701,279-294.

[3] Bellini, E., G. Giannelli, , E. Picardi, and E. Giordani 1989. New selection of very early ripening apricot obtained in florence. Acta. Hort. I. S. H. S. (293): 183 - 190.

[4] Cociu, V. 1991. Forty years of apricot breeding in Romania. Acta Horticulturae. 293: 197 - 201.

[5] Della Strada, G., C. Fideghelli, , F. Monastra, , F. Pennone, , and R. Quarta 1991. Apricot breeding at the Istituto sperimentale per la Frutticultura of Rome. Acta Horticulturae. 293 (1): $121-132$.

[6] Dejampour,J., H. Rahnemoun and D. Hassani 2005. Breeding almond interspecific hybrid rootstocks in Iran, IV International Symposium on Pistachios and almond (ISHS).

[7] Dejampour, J., and V. Grigorian. 2004. Effect of pollen type on some quantities and qualitative characteristics of apricot fruit .Iranian journal of horticultural science and technology. Vol. 5,No. 1.

[8] Dejampour, D., E. Majidi, , S. Khosravi, , S. Farhadi, , and A. Shadmehr, 2011. In vitro propagation of HS314 rootstock ( prunus amygdulus $\times$ P. persica). HortScience 46(6):928-931.

[9] Dejampour, J., H. Rahnemuon, E. Gangi Mogadam, N. Bozari and M. Zaribal. 2012. Maragheh 90, A New High Yielding Apricot Cultivar Suitable for Table and Processing Purposes. Iranian journal of Seed and plant Improvement. Vo28. 2,No. 4.

[10] Fathi, H. J. Dejampour, U. Jahani, and M. Zarrinbal.2012. Tree and fruit characterization of peach genotypes grown under Ardabil and East Azarbaijan environmental conditions in Iran

[11] Gulcan, Y., H. Dumanoglu, and B. Kunter, (1995) Fruit cracking in some Turkish apricot cultivars. Acta Horticulturae 384, 277-282.

[12] Guleryuz, M. 1993. Selection of the quality - fruited wild apricot (Prunus armeniaca L.) forms resistant to late spring frosts on Erzincan Plain. Act Hort. No: 384. 1995. p: 189 - 194.

[13] Ham, H. and Smith, C. (2006) Apricot breeding in South Africa - changing of climates. Acta Horticulturae 701, 389-393.

[14] Layne, R.E.C., C.H. Bailey. L.F. Hough.1996. Apricots. In: Janick, J., Moore, J.N. (Eds.) Fruit Breeding: Tree and Tropical Fruits, vol. II. John Wiley and Sons, New York. pp. 79-111.

[15] Okie, W.R., and J.F. Hancock,. 2008. Plums, pp. 337-358 Temperate Fruit Crop Breedeing. Springer, New York.

[16] Rahnemuon H, J. Dejampour, E. Gangi Mogadam, N. Bozari and M. Zaribal. 2012. Ordubad 90, A New High Yielding Apricot Cultivar Suitable for Processing

[17] Purposes.Iranian journal of of Seed and plant Improvement. Vo28. 2,No. 4.

[18] Singh, M. P., D. C. Dimri and M. C. Nautiral 2001. Determination of fruit maturity indices in Apricot (Prunus armeniaca L.) cv.New Castle. Journal of Applied Horticulture Lucknow.3:2. $108-110$.

[19] Vachun, Z. 2003. Phenophases of blossoming and picking maturity and their relationships in twenty apricot genotypes for a period of six years. Zahradnictvi Horticultural Science. 30:2. 4350 . 